\title{
Profit Growth, Size, Liquidity And Investment Opportunity Set On Earnings Quality (Studi Empiris Pada Perusahaan Manufaktur Sektor Consumer Goods Industry Yang Terdaftar Di Bursa Efek Indonesia Periode 2015-2019)
}

\author{
Ratu Ayu Mas Intan Siti Imaniyah ${ }^{1}$, Dian Maulita ${ }^{2}$ \\ Universitas Serang Raya ${ }^{1,2}$ \\ ${ }^{1}$ ratuayumasintansti@gmail.com, ${ }^{2}$ maulita.dian@gmail.com
}

\begin{abstract}
This study aims to examine the effect of Profit Growth, Size, Liquidity and Investment Opportunity Set on Earnings Quality in the consumer goods industry manufacturing companies listed on Indonesian Stock Exchange for the period 2015-2019. The research paradigm used is a quantitative paradigm with descriptive causality research methods. The population of this research were 55 companies and samples obtained were 29 companies with a purposive sampling method. Based on the results of the study, it can be concluded that: 1) profit growth has a significant effect on earnings quality, 2) size has no significant effect on earnings quality, 3) liquidity has a significant effect on earnings quality, 4) investment opportunity set has a significant effect on earnings quality, 5) profit growth, size, liquidity and investment opportunity set together have a significant effect on earnings quality.
\end{abstract}

Keywords: earnings quality, investment opportunity set, liquidity, profit growth, size

Laba yang termasuk ke dalam kategori yang diragukan kualitasnya adalah ketika suatu perusahaan menyajikan laba tidak sesuai dengan fakta yang sebenarnya mengenai kondisi ekonomi perusahaan (Paulus, 2012). Ketika perusahaan melakukan cara yang tidak sehat dalam meyajikan informasi labanya, tentu saja perusahaan tersebut telah melenceng dari karakteristik yang dimiliki oleh laporan keuangan itu sendiri, sehingga cara seperti ini akan mengakibatkan laba perusahaan tidak berkualitas karena tidak sesuai dengan fakta sebenarnya.

Fenomena yang merupakan tindakan manajemen laba seperti diatas pernah dilakukan oleh PT Kimia Farma (Persero) Tbk pada tahun buku 2001. Dalam laporan keuangan yang disajikan, Kimia Farma membukukan laba bersih sebesar Rp132 Miliar. Akan tetapi, Kementerian BUMN dan BAPEPAM menilai bahwa laba bersih tersebut terlalu besar dan mengandung unsur rekayasa. Setelah dilakukan audit ulang, pada 3 Oktober 2002 laporan keuangan Kimia Farma 2001 disajikan kembali (restated), karena telah ditemukan kesalahan yang cukup mendasar. Pada laporan keuangan yang baru, keuntungan yang disajikan hanya sebesar Rp99,56 Miliar atau lebih rendah sebesar Rp32,6 Miliar atau $24,7 \%$ dari laba awal yang dilaporkan. Pada akhirnya, Kimia Farma dikenakan sanksi dan denda. (sumber: davidparsaoran.wordpress.com)

Perusahaan manufaktur sektor consumer goods industry memiliki pertumbuhan laba yang tergolong mengesankan walaupun terkadang mengalami penurunan. Beberapa perusahaan besar seperti HMSP terutama, lalu di ikuti GGRM, UNVR, INDF dan ICBP sering unggul dalam 
menempati posisi tertinggi di sektor ini pada kategori perusahaan dengan pertumbuhan laba yang baik. Produk-produk yang selalu dibutuhkan membuat sektor ini memerlukan perhatian yang lebih terhadap aset lancar dan utang lancarnya agar aktivitas operasi lebih efisien. Oleh karena itu, perusahaan biasanya melakukan analisis terhadap laporan keungannya untuk mengetahui kelemahan dan kelebihan yang dimiliki oleh perusahaan. Ketertarikan investor terhadap sektor ini juga menjadi indikasi bahwa semakin ketatnya persaingan yang ada, sehingga masingmasing perusahaan perlu menciptakan inovasi-inovasi untuk mempertahankan pasar yang sudah dimiliki. Laba merupakan informasi yang akan menjadi pusat utama investor, tetapi melihat kasus yang sudah diuraikan sebelumnya, maka dapat dikatakan bahwa tidak semua laba dapat mencerminkan earnings quality yang dimiliki.

Earnings Quality merupakan laba dalam laporan keuangan yang secara benar dan akurat mencerminkan kinerja keuangan perusahaan. Manajemen laba merupakan suatu bentuk akuntansi yang dirancang dengan maksud untuk mendapatkan beberapa keuntungan pribadi. Ketika manajemen laba sering dilakukan hal tersebut menandakan bahwa earnings quality perusahaan tersebut akan menjadi rendah karena suatu laba dikatakan berkualitas apabila mencerminkan keadaan perusahaan yang sesungguhnya, tetapi dikatakan tidak berkualitas apabila laba yang disajikan berdasarkan keputusan sendiri dan kepentingan pribadi. Terdapat hubungan negatif antara Earnings quality dan manajemen laba yang artinya apabila tingkat manajemen laba yang dilakukan tinggi maka earnings quality akan semakin rendah dan begitupun sebaliknya (Sutopo, 2012) dalam (Shanty \& Julianti, 2018).

Profit growth merupakan salah satu faktor dari earnings quality. Jika perusahaan memiliki kesempatan untuk menumbuhkan labanya, maka perusahaan tersebut dapat dikatakan aman dan laba yang akan didapatkan di masa yang akan datang, akan menjadi laba yang berkualitas. Laba kejutan atau kenaikan laba yang sangat signifikan yang terjadi didalam suatu perusahaan, oleh investor di respon sebagai suatu indikasi adanya intervensi dari pihak manajemen perusahaan terhadap laporan keuangan sehingga laba mengalami peningkatan yang terlalu tinggi dari laba yang di dapatkan tahun sebelumnya. Profit growth perusahaan yang seperti itu tidaklah membuat earnings quality menjadi yang tinggi, melainkan akan menjadikan earnings quality perusahaan tersebut menjadi rendah (Dira \& Astika, 2014). Dilihat dari hasil penelitian Kartika Aulia Zein (2016), profit growth berpengaruh secara signifikan terhadap earnings quality. Sedangkan dalam penelitian Chusnul Khotimah (2016), profit growth tidak dapat mempengaruhi earnings quality yang artinya nilai profit growth semakin tinggi atau rendah maka nilai earnings quality juga tidak dipengaruhi semakin tinggi atau rendahnya.

Faktor lain yang dapat memperngaruhi earnings quality adalah size perusahaan. Ketika suatu perusahaan memiliki size yang besar, maka kelangsungan usaha perusahaan tersebut semakin tinggi dan hal tersebut 
dapat meningkatkan labanya, sehingga laba yang didapatkannya akan menjadi laba yang berkualitas. Semakin besar penjualan menandakan perputaran uang semakin banyak dan semakin besar aktiva menandakan modal yang ditanam semakin banyak (Wulandari, 2018). Size perusahaan yang kecil dianggap lebih banyak melakukan praktik manajemen laba daripada perusahaan besar. Hal ini disebabkan karena perusahaan kecil cenderung ingin memperlihatkan kondisi perusahaan yang selalu berkinerja baik agar investor menanamkan modalnya pada perusahaan tersebut sehingga tanpa disadari membuat perusahaan tersebut memiliki earnings quality yang rendah. Berbeda dengan perusahaan kecil, perusahaan besar biasanya akan lebih berhati-hati dalam melakukan pelaporan keuangan, karena perusahaan yang besar lebih diperhatikan oleh masyarakat (Medyawati \& Dayanti, 2016). Dalam penelitian Bagus Rahmat Setiawan (2017) menunjukan hasil penelitian bahwa size perusahaan memiliki pengaruh terhadap earnings quality. Sedangkan dalam penelitian Siti Wulandari (2018) Size tidak berpengaruh terhadap earnings quality.

Pada dasarnya, dalam suatu pasar ekonomi, perusahaan yang memiliki kemampuan yang baik dalam menghasilkan labanya akan mendapatkan respon yang lebih besar karena hal tersebut menandakan bahwa tingkat investment opportunity set yang dimiliki perusahaan itu tinggi. Tingkat investment opportunity set perusahaan yang tinggi memiliki arti bahwa perusahaan tersebut memiliki kesempatan bertumbuh yang baik (Mulyani et al. 2007) dalam (Fauzi et al. 2015). Apabila perusahaan memiliki tingkat kesempatan tumbuh yang tinggi, maka perusahaan tersebut akan melakukan perluasan terhadap usahanya sehingga dana yang akan dibutuhkan makin banyak. Sedangkan apabila perusahaan memiliki investment opportunity set yang rendah maka perusahaan tersebut tentunya kemampuan memperoleh laba di masa depannya akan rendah pula dan hal tersebut akan berpengaruh terhadap earnings quality, karena tentunya disebabkan adanya dorongan untuk menarik perhatian pihak eksternal sehingga dilakukannya manipulasi laba. Penelitian yang dilakukan oleh Reza Fahlevi (2016) menghasilkan bahwa investment opportunity set berpengaruh terhadap earnings quality. Sedangkan penelitian yang dilakukan oleh Pramesheila Ayu Budiani (2019) memperoleh hasil penelitian bahwa investment opportunity set tidak berpengaruh terhadap earnings quality.

Dari uraian hasil penelitian sebelumnya diatas, dapat disimpulkan bahwa terdapat perbedaan dalam hasil penelitian. Maka penulis ingin meneliti ulang dengan memilih Profit Growth, Size, Liquidity dan Investment Opportunity Set (IOS) sebagai variabel yang mempengaruhi Earnings Quality. Oleh karena itu, penulis mengambil judul "Profit Growth, Size, Liquidity and Investment Opportunity Set (IOS) on Earnings Quality pada Perusahaan Manufaktur Sektor Consumer Goods Industry yang Terdaftar di Bursa Efek Indonesia Periode 20152019". 


\section{METODE}

Dalam penelitian ini, penulis akan menggunakan Teknik pengambilan sampel purposive sampling.

Analisis data dalam penelitian ini meliputi :

1. Uji Statistik Deskriptif

Statistik deskriptif merupakan statistik penelitian yang digunakan untuk menganalisa data dengan cara mendeskripsikan atau menggambarkan data yang telah terkumpul sebagaimana adanya tanpa bermaksud mengambil kesimpulan yang berlaku umum. Statistik deskriptif adalah penyajian data dengan tabel, grafik, diagram, lingkaran, piktogram, perhitungan modus, median, mean presentase, standar deviasi dan lain sebagainya. Statistik deskriptif dapat digunakan pada penelitian yang dilakukan pada populasi dan juga dapat digunakan pada penelitian yang dilakukan pada sampel.

2. Uji Asumsi Klasik

Uji asumsi klasik bertujuan untuk memberikan kepastian bahwa persamaan regresi yang di dapatkan memiliki ketepatan dalam estimasi tidak bias dan konsisten. Uji asumsi klasik terdiri dari:

1) Uji Normalitas

Uji ini bertujuan untuk menguji apakah dalam sebuah model regresi, variabel independen, variabel dependen atau keduanya mempunyai distribusi normal atau tidak. Hal ini bertujuan untuk mengetahui jenis statistik yang cocok yang akan digunakan dalam menganalisis data. Uji normalitas dilakukan didalam penelitian ini adalah Kolmogorov-Smirnov.

2) Uji Multikolinearitas

Untuk mendeteksi ada atau tidaknya multikolinearitas didalam model regresi penelitian ini adalah dengan melihat nilai Tolerance dan Variance Inflation Factor (VIF). Nilai cut-off yang umum dipakai untuk melihat multikolinearitas adalah nilai Tolerance $\leq 0,10$ atau sama dengan nilai VIF $\geq 10$ (Ghozali,2018:107-108).

3) Uji Autokorelasi

Uji autokorelasi bertujuan untuk menguji apakah dalam model regresi linear ada korelasi antara kesalahan pengganggu pada periode $t$ dengan kesalahan pengganggu pada periode sebelumnya. Untuk mendiagnosis adanya autokorelasi dalam suatu model regresi dilakukan melalui pengujian Durbin-Watson (DW).

4) Uji Heterokedastisitas

Uji Heteroskedastisitas bertujuan untuk menguji apakah dalam model regresi terjadi atau terdapat ketidaksamaan varians dari residual dari satu pengamatan ke pengamatan yang lain. Cara memprediksi ada tidaknya heteroskedastisitas pada suatu model dapat dilihat dari pola gambar Scatterplot model tersebut. 
3. Uji Regresi Linear Berganda

Analisis linear berganda dilakukan untuk mengolah dan membahas data yang telah diperoleh dan untuk menguji hipotesis yang diajukan menggunakan persamaan:

$$
Y^{\prime}=a+b_{1} X_{1}+b_{2} X_{2}+\ldots+b_{n} X_{n}
$$

Keterangan:

$\mathrm{Y}^{\prime} \quad=$ Variabel dependen (nilai yang diprediksikan)

$\mathrm{X}_{1,2}$ dan $\mathrm{X}_{\mathrm{n}}=$ Variabel independen

a $\quad=$ Konstanta (nilai $Y^{\prime}$ apabila $X_{1}, X_{2} \ldots . . X_{n}=0$ )

$\mathrm{b}=$ Koefisien regresi (nilai peningkatan atau penurunan)

4. Uji Hipotesis

1) Uji Signifikansi Parsial (Uji t)

Uji parsial digunakan untuk mengetahui pengaruh variabel independen terhadap variabel dependen secara individu (Gozali, 2018:179). Untuk menentukan besarnya t-hitung dapat digunakan rumus sebagai berikut:

Keterangan:

$\mathrm{t}=$ Distribusi $\mathrm{t}$

bi $\quad=$ Koefisien regresi variabel

Sbi $=$ Standar error koefisien regresi

Hasil perhitungan ini selanjutnya dibandingkan dengan ttabel dengan menggunakan tingkat kesalahan 0,05 atau dengan degree of freedom (df) n-k.

2) Uji Signifikansi Simultan (Uji F)

Uji Statistik $F$ pada dasarnya menunjukan apakah semua variabel independen yang dimasukan dalam model mempunyai pengaruh secara bersama-sama terhadap variabel dependen (Ghozali, 2018:179). Menurut Sugiyono (2019:284), rumus yang dapat digunakan adalah:

Keterangan:

$$
F=\frac{R^{2} / k}{\left(1-R^{2}\right) /(n-k-1)}
$$

$R^{2} \quad=$ Koefisien determinasi

$k \quad=$ Jumlah variabel independen

$n \quad=$ Jumlah anggota data atau kasus

Hasil perhitungan ini dibandingkan dengan F-tabel yang diperoleh dengan menggunakan tingkat resiko atau signifikan level $5 \%$ atau dengan degree freedom $=k(n-k-1)$.

5. Uji Koefisien Determinasi $\left(\mathrm{R}^{2}\right)$

Koefisien determinasi $\left(R^{2}\right)$ pada intinya mengukur seberapa jauh kemampuan model dalam menerangkan variasi variabel dependen. Nilai koefisien determinasi antara satu atau nol. Nilai $R^{2}$ yang lebih 
kecil berarti kemampuan variabel independen dalam menjelaskan variasi variabel dependen sangat terbatas. Nilai $R^{2}$ yang mendekati satu berarti variabel-variabel independen memberikan hampir semua informasi yang dibutuhkan untuk memprediksi variasi variabel dependen.

\section{HASIL}

1. Hasil Uji Statistik Deskriptif

Tabel 1. Hasil Uji Statistik Deskriptif

Descriptive Statistics

\begin{tabular}{|l|r|r|r|r|r|}
\hline & N & Minimum & Maximum & Mean & $\begin{array}{c}\text { Std. } \\
\text { Deviation }\end{array}$ \\
\hline Profit Growth & 106 & $-3,23$ & 2,05 &, 1262 &, 52717 \\
\hline Size & 106 & 26 & 32 & 28,97 & 1,618 \\
\hline Liquidity & 106 & 1,00 & 8,32 & 2,7874 & 1,48037 \\
\hline $\begin{array}{l}\text { Investment } \\
\text { Opportunity Set } \\
\text { (IOS) }\end{array}$ & 106 &, 17 & 7,07 & 2,7208 & 1,92415 \\
\hline Earnings Quality & 106 &,- 21 & 3,50 & 1,2542 &, 71823 \\
\hline Valid N (listwise) & 106 & & & & \\
\hline
\end{tabular}

(Sumber: Output SPSS 25, data diolah 2020)

2. Hasil Uji Asumsi Klasik

1) Hasil Uji Normalitas

Uji Normalitas bertujuan untuk menguji apakah dalam model regresi, variabel pengganggu atau residual memiliki distribusi normal. Pengujian normalitas data dalam penelitian ini menggunakan uji statistik non-parametrik Kolmogorov-Smirnov (K-S). Hasil Uji Normalitas dapat dilihat dari tabel berikut:

Tabel 2. Hasil Uji Normalitas

One-Sample Kolmogorov-Smirnov Test

\begin{tabular}{|c|c|c|}
\hline & & $\begin{array}{c}\text { Unstandardized } \\
\text { Residual } \\
\end{array}$ \\
\hline $\mathrm{N}$ & & 106 \\
\hline Normal Parameters ${ }^{\mathrm{a}, \mathrm{b}}$ & Mean &, 0000000 \\
\hline & Std. Deviation & 65777703 \\
\hline Most Extreme Differences & Absolute & ,063 \\
\hline & Positive & ,063 \\
\hline & Negative &,- 029 \\
\hline Test Statistic & &, 063 \\
\hline Asymp. Sig. (2-tailed) & & $200^{c, d}$ \\
\hline a. Test distribution is Norm & & \\
\hline b. Calculated from data. & & \\
\hline c. Lilliefors Significance Co & ction. & \\
\hline d. This is a lower bound of & true signific & \\
\hline
\end{tabular}

(Sumber: Output SPSS 25, data diolah 2020)

Berdasarkan Tabel 2. Hasil Uji Normalitas menunjukan bahwa data terdistribusi normal. Hal tersebut dapat dilihat dari nilai Test Statistic Kolmogorov-Smirnov adalah 0,063 dan signifikan pada 0,200 yang menunjukan bahwa nilai signifikansi 0,200 lebih besar dari 0,05.

2) Hasil Uji Multikolinearitas

Tujuan dilakukannya uji multikolinearitas adalah untuk menguji ada tidaknya di dalam model regresi terdapat korelasi antara variabel independen. Model regresi yang baik seharusnya tidak terjadi 
korelasi di antara variabel independen. Dalam penelitian ini, untuk melihat ada tidaknya multikolinearitas adalah dengan nilai Tolerance $\leq 0,10$ atau sama dengan nilai VIF $\geq 10$. Berikut adalah hasil Uji Multikolinearitas penelitian ini:

Tabel 3. Hasil Uji Multikolinearitas

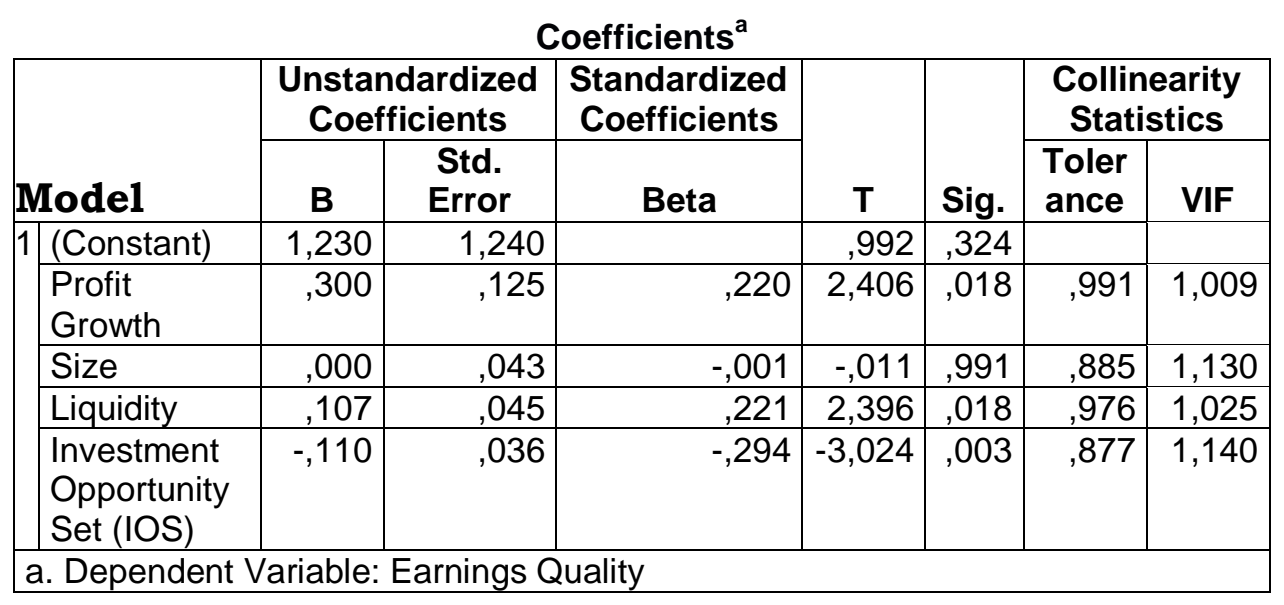

(Sumber: Output SPSS 25, data diolah 2020)

Berdasarkan hasil Uji Multikolinearitas pada Tabel 3. Hasil Uji Multikolinearitas, diketahui bahwa nilai VIF seluruh variabel kurang dari 10 dan nilai tolerance seluruh variabel lebih dari 0,10 . Hal ini menunjukan bahwa tidak ada multikolinearitas antar variabel independen dalam model regresi.

3) Hasil Uji Autokorelasi

Uji Autokorelasi bertujuan menguji apakah dalam model regresi linear ada korelasi antara kesalahan pengganggu pada periode $t$ dengan kesalahan pengganggu pada periode t-1 (sebelumnya). Jika terjadi korelasi, maka dinamakan ada problem autokorelasi. Autokorelasi muncul karena observasi yang berurutan sepanjang waktu berkaitan satu sama lain. Msaalah ini timbul karena residual (kesalahan pengganggu) tidak bebas dari satu observasi ke observasi lainnya. Uji yang digunakan dalam uji autokorelasi di dalam penelitian ini adalah Uji Durbin-Watson (DW). Berikut adalah hasil Uji Autokorelasi dari penelitian ini:

Tabel 4. Hasil Uji Autokorelasi

[odel Summary ${ }^{\mathrm{b}}$

\begin{tabular}{|l|c|r|r|r|r|}
\hline Model & R & R Square & $\begin{array}{c}\text { Adjusted R } \\
\text { Square }\end{array}$ & $\begin{array}{l}\text { Std. Error of } \\
\text { the Estimate }\end{array}$ & $\begin{array}{l}\text { Durbin- } \\
\text { Watson }\end{array}$ \\
\hline 1 &, $402^{\mathrm{a}}$ &, 161 &, 128 &, 67068 & 1,810 \\
\hline
\end{tabular}

a. Predictors: (Constant), Investment Opportunity Set (IOS), Profit Growth, Liquidity, Size

b. Dependent Variable: Earnings Quality

(Sumber: Output SPSS 25, data diolah 2020) 
Berdasarkan Tabel 4. Hasil Uji Autokorelasi, nilai DW sebesar 1,810, nilai ini dibandingkan dengan nilai tabel dengan menggunakan signifikansi 5\%, jumlah sampel $106(\mathrm{n})$ dan jumlah variabel independen $4(k=4)$, maka tabel Durbin Watson akan didapatkan sebagai berikut:

Tabel 5. Durbin-Watson Test Bound

\begin{tabular}{|c|c|c|}
\hline & $\mathrm{K}=\mathbf{4}$ & \\
\hline $\mathrm{N}$ & $\mathrm{dL}$ & $\mathrm{dU}$ \\
\hline 15 & 0.6852 & 1.9774 \\
$\cdot$ & $\cdot$ & $\cdot$ \\
106 & 1.6061 & 1.7624 \\
\hline
\end{tabular}

Oleh Karena nilai DW 1,810 lebih besar dari batas atas (dU) 1,7624 dan kurang dari $4-1,7624(4-\mathrm{dU})$ atau:

$$
1,7624<1,810<2,2376
$$

Maka dapat disimpulkan bahwa kita tidak bisa menolak $\mathrm{HO}=$ tidak ada autokorelasi, atau yang berarti $\mathrm{HO}$ diterima dan menunjukan tidak adanya autokorelasi.

4) Hasil Uji Heteroskedastisitas

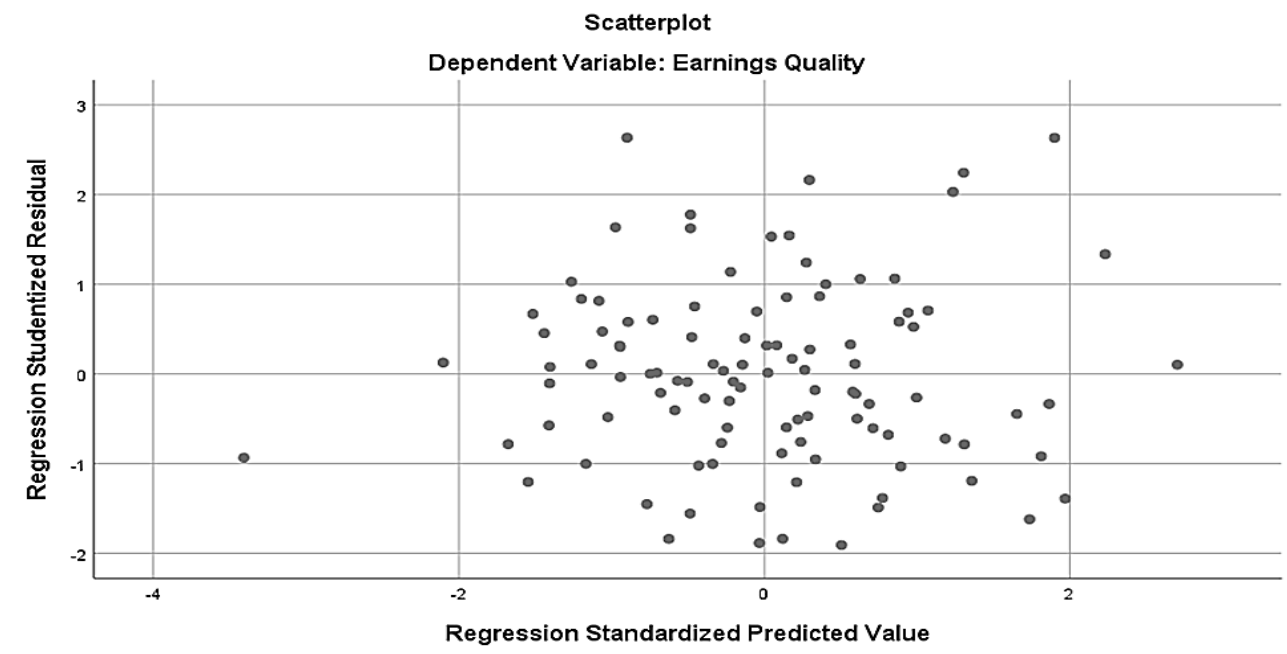

(Sumber : Output SPSS 25, data diolah 2020)

Gambar 1. Hasil Uji Heteroskedastisitas

Dari grafik scatterplot terlihat bahwa titik-titik menyebar secara acak serta tersebar baik diatas maupun dibawah angka 0 pada sumbu Y. Hal ini dapat disimpulkan bahwa tidak terjadi heteroskedastisitas pada model regresi.

3. Hasil Uji Regeresi Linear Berganda

Tabel 6. Hasil Uji Regresi Linear Berganda Coefficients $^{\mathrm{a}}$ 


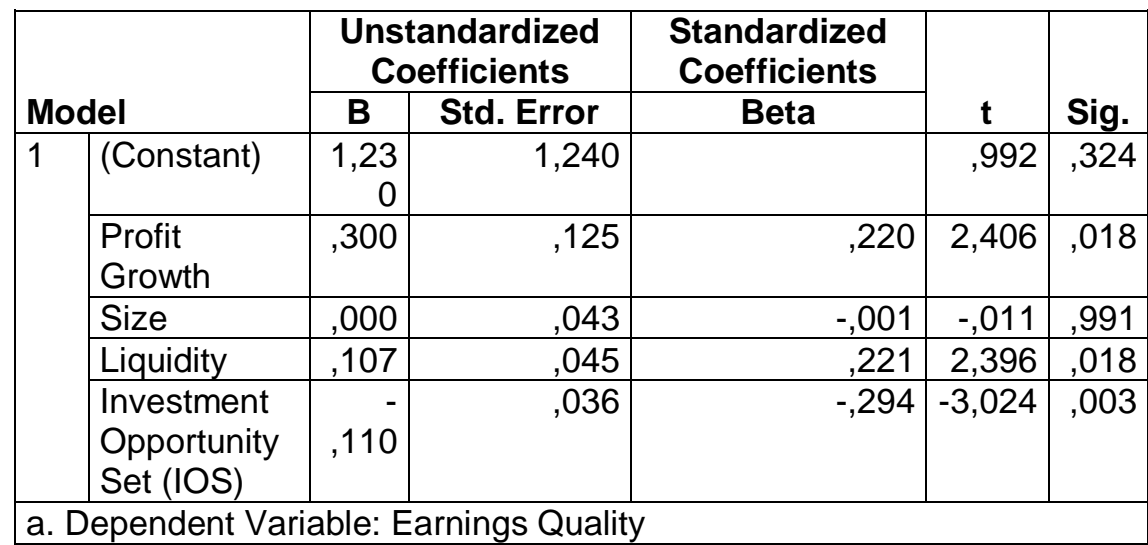

(Sumber : Output SPSS 25, data diolah 2020)

Berdasarkan Tabel 6. Hasil Uji Regresi Linear Berganda dapat diketahui bahwa persamaan regresi yang terbentuk adalah:

$$
Y=1,230+0,300 X_{1}+0,000 X_{2}+0,107 X_{3}-0,110 X_{4}+e
$$

4. Hasil Uji Hipotesis

1) Hasil Uji Signifikansi Parsial (Uji t)

Tabel 7. Hasil Uji t Coefficients $^{\mathrm{a}}$

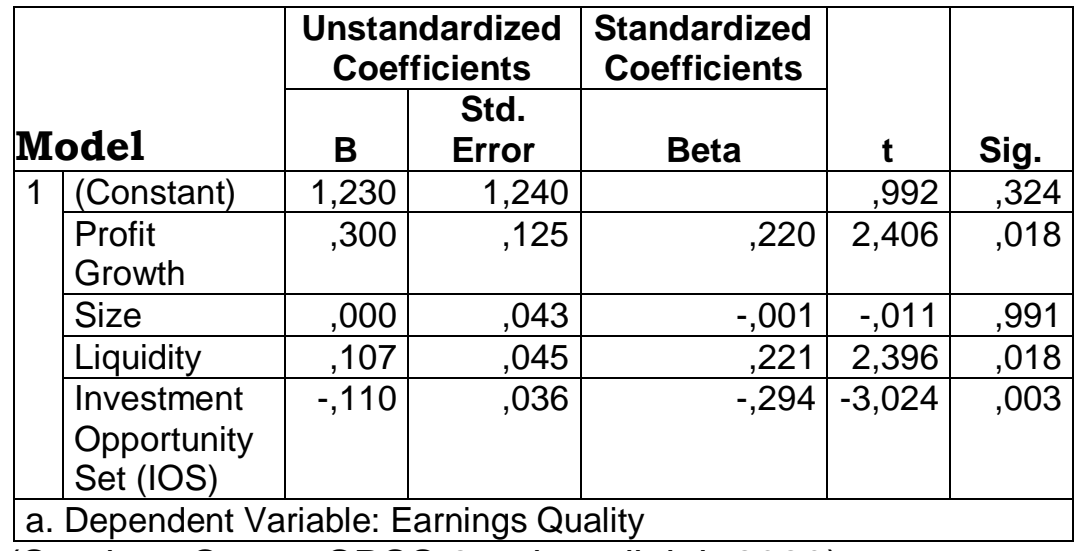

(Sumber: Output SPSS 25, data diolah 2020)

T-tabel yang dihasilkan adalah sebesar 1,98373 dengan perhitungan:

$$
\begin{aligned}
\text { T tabel } & =(\alpha ; \mathrm{n}-\mathrm{k}) \\
\mathrm{T} \text { tabel } & =(0,05 ; 106-5) \\
\mathrm{T} \text { tabel } & =(0,05 ; 101) \\
T \text { tabel } & =1,98373
\end{aligned}
$$

Berdasarkan hasil output SPSS pada Tabel 7. Hasil Uji t dapat diketahui bahwa:

1. Pada variabel profit growth, nilai signifikansi yang didapatkan sebesar 0,018. Hal tersebut menunjukan 0,018<0,05 yang memiliki arti bahwa hipotesis 1 diterima dan Ho ditolak. Begitu 
juga apabila t-statistik dibandingkan dengan t-tabel menghasilkan 2,406 > 1,98373 yang menunjukan kesimpulan yang sama. Maka dapat disimpulkan bahwa profit growth berpengaruh terhadap earnings quality.

2. Pada variabel size, nilai signifikansi yang didapatkan sebesar 0,991 dan $t$ statistik menunjukan nilai $-0,11$. Hal tersebut menunjukan 0,991 > 0,05 dan -1,98373 <-0,11<1,98373 yang memiliki arti bahwa hipotesis 2 ditolak dan Ho diterima. Maka dapat disimpulkan bahwa profit growth tidak berpengaruh terhadap earnings quality.

3. Pada variabel liquidity, nilai signifikansi yang didapatkan sebesar 0,018 dan $t$ statistik menunjukan nilai 2,396. Hal tersebut menunjukan 0,018<0,05 dan 2,396 > 1,98373 yang memiliki arti bahwa hipotesis 3 diterima dan Ho ditolak dan menunjukan bahwa liquidity berpengaruh terhadap earnings quality.

4. Pada variabel investment opportunity set, nilai signifikansi yang didapatkan sebesar 0,003 dan nilai t statistik -3,024. Hal tersebut menunjukan 0,003 0,05 dan apabila nilai statistik yang negatif (-) dibandingkan dengan t tabel (-) menunujukan -3,024 < 1,98373. Hal tersebut memiliki arti bahwa Ho ditolak dan hipotesis 4 diterima. Maka dapat disimpulkan bahwa investment opportunity set memiliki pengaruh yang signifikan terhadap earnings quality.

4. Hasil Uji Signifikansi Simultan (Uji F)

Tidak seperti uji $\mathrm{t}$ yang menguji signifikansi secara individu (parsial), uji $\mathrm{F}$ dilakukan untuk mengetahui pengaruh variabel independen terhadap variabel dependen secara bersama-sama (simultan). Berikut adalah hasil dari uji $\mathrm{F}$ penelitian ini:

Tabel 8. Hasil Uji F

\begin{tabular}{|c|c|c|c|c|c|c|}
\hline \multicolumn{7}{|c|}{ ANOVA $^{\mathrm{a}}$} \\
\hline \multicolumn{2}{|c|}{ Model } & $\begin{array}{l}\text { Sum of } \\
\text { Squares }\end{array}$ & Df & $\begin{array}{l}\text { Mean } \\
\text { Square }\end{array}$ & $\mathbf{F}$ & \\
\hline \multirow{3}{*}{$\begin{array}{cc}1 & \mathrm{u} \\
\mathrm{m} & \mathrm{b}\end{array}$} & Regression & 8,735 & 4 & 2,184 & 4,855 &, $001^{\mathrm{D}}$ \\
\hline & Residual & 45,430 & 101 & ,450 & & \\
\hline & Total & 54,165 & 105 & & & \\
\hline \multicolumn{7}{|c|}{ a. Wependent Variable: Earnings Quality } \\
\hline
\end{tabular}

Output SPSS 25, data diolah 2020)

F-tabel yang dihasilkan:

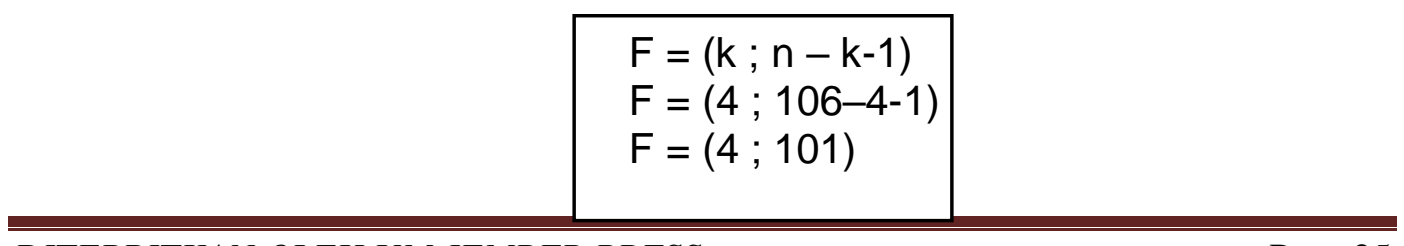




$$
\mathrm{F}=2,46
$$

Berdasarkan Tabel 8. Hasil Uji $F$ menunjukan bahwa signifikansi sebesar 0,001 . Nilai signifikansi tersebut menunjukan $0,001<0,05$ yang berarti bahwa Profit Growth, Size, Liquidity, dan Investment Opportunity Set (IOS) secara bersama-sama memiliki pengaruh terhadap Earnings Quality. Apabila uji F dilakukan dengan membandingkan F-Statistik dengan F-Tabel maka menghasilkan 4,855 > 2,46 yang berarti hipotesis 5 pun di terima dan Ho ditolak atau Profit Growth, Size, Liquidity, dan Investment Opportunity Set (IOS) secara bersama-sama memiliki pengaruh signifikan terhadap Earnings Quality.

5. Hasil Uji Koefisien Determinasi $\left(\mathrm{R}^{2}\right)$

Tabel 9. Hasil Uji Koefisien Determinasi $\left(\mathbf{R}^{2}\right)$

Model Summary ${ }^{\mathrm{b}}$

\begin{tabular}{|l|c|r|r|r|r|}
\hline Model & $\mathbf{R}$ & $\mathbf{R}$ Square & $\begin{array}{c}\text { Adjusted R } \\
\text { Square }\end{array}$ & $\begin{array}{c}\text { Std. Error of } \\
\text { the Estimate }\end{array}$ & $\begin{array}{c}\text { Durbin- } \\
\text { Watson }\end{array}$ \\
\hline 1 &, $402^{\mathrm{a}}$ &, 161 &, 128 &, 67068 & 1,810 \\
\hline $\begin{array}{l}\text { a. Predictors: (Constant), Investment Opportunity Set (IOS), Profit Growth, } \\
\text { Liquidity, Size }\end{array}$ \\
b. Dependent Variable: Earnings Quality \\
\hline
\end{tabular}

(Sumber: Output SPSS 25, data diolah 2020)

Berdasarkan Tabel 9. Hasil Uji Koefisien Determinasi, nilai Adjusted R Square sebesar 0,128 atau $12,8 \%$ artinya variasi variabel profit growth, size, liquidity dan investment opportunity set mampu menerangkan dan menjelaskan $12,8 \%$ variasi variabel earnings quality. Sedangkan sisanya $87,2 \% \quad(100 \%-12,8 \%)$ dijelaskan oleh faktor lain yang tidak ada didalam penelitian ini.

\section{Pengaruh Profit Growth Terhadap Earnings Quality}

Berdasarkan hasil tersebut dapat dikatakan bahwa rendah atau tingginya profit growth perusahaan akan mempengaruhi rendah atau tingginya tingkat earnings quality. Apabila perusaahan memiliki profit growth yang terus menerus meningkat dari tahun ke tahun, maka hal tersebut dapat memberikan sinyal yang positif mengenai prospek perusahaan di masa depan. Perusahaan yang memiliki profit growth tinggi tidak perlu melakukan praktik manipulasi laba, sehingga earnings quality perusahaan tetap baik. Sedangkan, perusahaan yang memiliki profit growth rendah kemungkinan akan melakukan manipulasi laba demi menarik para investor, memudahkan melakukan pinjaman dan lainnya yang akan meyebabkan tingkat earnings quality menjadi rendah. Hasil penelitian ini sejalan dengan penelitian (Zein, 2016) dan (Wulandari, 2018) yang memiliki hasil penelitian yang menyatakan bahwa profit growth berpengaruh signifikan terhadap earnings quality. 


\section{Pengaruh Size Terhadap Earnings Quality}

Perusahaan yang memiliki total asset yang berjumlah besar dan tergolong kedalam perusahaan dengan size besar atau bahkan perusahaan tersebut merupakan perusahaan yang labanya stabil, hal tersebut tidak menjamin perusahaan tersebut memiliki earnings quality yang baik pula. Bisa saja perusahaan yang memiliki total asset dalam jumlah besar masih memiliki tanggungjawab yang besar pula untuk mendanai kewajiban perusahaan. Hal tersebut dikarenakan, perusahaan yang memiliki size yang besar akan memiliki potensi mendapatkan keuntungan yang besar, memiliki risiko yang besar dan tentunya untuk mengelola kegiatan operasional perusahaannya membutuhkan dana yang besar pula. Hal tersebut memicu pihak eksternal lebih memilih melihat faktor lain selain total asset untuk mengetahui earnings quality perusahaan tersebut. Hasil penelitian ini sejalan dengan (Wulandari, 2018) dan (Budiani, 2019) yang meyatakan bahwa size tidak berpengaruh terhadap earnings quality.

\section{Pengaruh Liquidity Terhadap Earnings Quality}

Liquidity didalam penelitian ini diukur menggunakan current ratio. Semakin besar perbandingan dari aktiva lancarnya dengan utang lancarnya, maka akan semakin tinggi juga kemampuan sebuah perusahaan dalam menutupi kewajiban lancarnya. Hal penting yang harus dilakukan perusahaan adalah mempertahankan tingkat liquidity. Apabila perusahaan mampu mempertahankan tingkat liquiditynya maka perusahaan tersebut bisa mendapatkan kepercayaan dari pihak eksternal. Selain pihak eksternal memperhatikan laba perusahaan, dengan mengetahui tingkat liquidity perusahaan juga dapat membantu pihak eksternal untuk mengambil keputusan dalam menanamkan modal, memberikan pinjaman ataupun yang lainnya. Secara teori, perusahaan yang memiliki tingkat liquidity rendah cenderung memiliki tingkat risiko yang tinggi, dengan demikian tingkat liquidity dapat menjadi bahan pertimbangan dalam pengambilan keputusan investasi. Dengan melihat tingkat liquidity perusahaan yang tetap bertahan atau bahkan meningkat tetapi tidak terlalu melonjak, pihak eksternal mungkin akan semakin percaya terhadap earnings quality yang dimiliki perusahaan tersebut. Hasil penelitian ini sejalan dengan (Maulita \& Putri, 2019), (Fahlevi, 2016)dan (Zein, 2016) yang menyatakan bahwa liquidity berpengaruh signifikan terhadap earnings quality.

\section{Pengaruh Investment Opportunity Set Terhadap Earnings}

\section{Quality}

Perusahaan dengan tingkat investment opportunity set tinggi akan memiliki prospek pertumbuhan perusahaan yang tinggi dimasa depan. Adanya kesempatan bertumbuh ditandai dengan adanya kesempatan investasi menyebabkan laba perusahaan dimasa depan 
akan meningkat. Sehingga pasar akan memberi respon yang lebih besar terhadap perusahaan.

Dalam penelitian ini, investment opportunity set memiliki koefisien regresi dengan arah negatif yang berarti bahwa apabila tingkat investment opportunity set semakin tinggi, maka tingkat earnings quality semakin menurun. Investment opportunity set (IOS) memiliki peranan yang sangat penting bagi perusahaan, karena IOS merupakan keputusan investasi dalam bentuk kombinasi dari aktiva yang dimiliki (assets in place) dan opsi investasi di masa yang akan datang, dimana IOS tersebut akan mempengaruhi nilai suatu perusahaan (Hidayah, 2017). Apabila perusahaan memiliki nilai perusahaan yang baik, maka banyak investor yang tertarik untuk menanamkan modalnya dan menaruh harapan yang besar atas investasinya dan kemungkinan manajemen perusahaan akan melakukan cara apapun supaya perusahaan tersebut terlihat dapat mempertahankan nilai perusahaannya. Salah satu kemungkinan yang akan dilakukan adalah melakukan perubahan angka laba yang tercatat didalam laporan keuangan.

Penelitian ini mendukung agency theory yang memiliki asumsi bahwa agent memiliki informasi yang lebih banyak dibandingkan principal sehingga agent bisa merubah angka-angka yang disajikan di dalam laporan keuangan demi mempertahankan ketertarikan investor terhadap perusahaan. Hasil penelitian ini sejalan dengan (Rosmaryam, 2015) dan (Alves, 2014) yang menyatakan bahwa investment opportunity set berpengaruh terhadap earnings quality.

\section{KESIMPULAN}

Berdasarkan hasil analisis data yang dilakukan pada bab sebelumnya, maka dapat ditarik kesimpulan sebagai berikut:

1. Profit Growth berpengaruh signifikan terhadap Earnings Quality pada perusahaan manufaktur sektor consumer goods industry yang terdaftar di Bursa Efek Indonesia periode 2015-2019.

2. Size tidak berpengaruh signifikan terhadap Earnings Quality pada perusahaan manufaktur sektor consumer goods industry yang terdaftar di Bursa Efek Indonesia periode 2015-2019.

3. Liquidity berpengaruh signifikan terhadap Earnings Quality pada perusahaan manufaktur sektor consumer goods industry yang terdaftar di Bursa Efek Indonesia periode 2015-2019.

4. Investment Opportunity Set (IOS) berpengaruh signifikan terhadap Earnings Quality pada perusahaan manufaktur sektor consumer goods industry yang terdaftar di Bursa Efek Indonesia periode 20152019.

5. Profit Growth, Size, Liquidity dan Investment Opportunity Set (IOS) secara simultan berpengaruh signifikan terhadap Earnings Quality 
pada perusahaan manufaktur sektor consumer goods industry yang terdaftar di Bursa Efek Indonesia periode 2015-2019.

\section{DAFTAR PUSTAKA}

Brigham, Eugene F., dan Houston, Joel. (2010). Dasar-Dasar Manajemem Keuangan. Jakarta : Salemba Empat.

Ghozali, Imam (2018). Aplikasi Analisis Multivariate Dengan Program IBM SPSS 25. Edisi 9. Semarang : Badan Penerbit Universitas Diponegoro.

Harahap, Sofyan Syafri. (2011). Teori Akuntansi. Ed. Revisi Cetakan Ke11. Jakarta : Rajawali Pers

Munawir. (2010). Analisa Laporan Keuangan. Cetakan Ke-15. Jakarta : Liberty Yogyakarta.

Sanusi, Anwar. (2017). Metodologi Penelitian Bisnis. Cetakan Ke-7. Jakarta : Salemba Empat.

Sugiyono. (2019). Metode Penelitian Kuantitatif. Bandung : Alfabeta

Alves, S. (2014). "The Effect Of Board Independence On The Earnings Quality: Evidence From Portuguese Listed Companies." 8(3), 23-44. Https://Doi.Org/10.14453/Aabfj.V8i3.3

Budiani, P. A. (2019). "Pengaruh Struktur Modal, Likuiditas, Investment Opportunity Set (IOS), dan Ukuran Perusahaan Terhadap Kualitas Laba" Artikel.

Dechow, P. M., Ge, W., \& Schrand, C. M. (2010). "Understanding Earnings Quality: A Review of the Proxies, Their Determinants and Their Consequences." SSRN Electronic Journal, (August). https://doi.org/10.2139/ssrn.1485858

Dewi, C. (2018). "Pengaruh Ukuran Perusahaan, Struktur Modal, Likuiditas, Investment Opportunity Set Dan Pertumbuhan Laba Terhadap Kualitas Laba Perusahaan (Studi Pada Perusahaan Manufaktur Yang Terdaftar Di Bursa Efek Indonesia Periode 20142016)." (1), 1-93. Https://Doi.Org/ISSN 2252-6765

Fahlevi, Reza. (2016). "Investment Opportunity Set, Voluntary Disclosure, Leverage, Dan Likuiditas Terhadap Kualitas Laba.” Skripsi: Fakultas Ekonomi Dan Bisnis Universitas Islam Negeri Syarif Hidayatullah Jakarta.

Hidayah, Nurul. (2017). "Pengaruh Investment Opportunity Set (los) dan Kepemilikan Manajerial Terhadap Nilai Perusahaan pada Perusahaan Property Dan Real Estat Di Bursa Efek Indonesia." Jurnal Akuntansi, 19(3), 420. Https://Doi.Org/10.24912/Ja.V19i3.89

Khotimah, Chusnul. (2016). "Pengaruh Pertumbuhan Laba, Konservatisme Akuntansi, Investment Opportunity Set, Dan Leverage Terhadap Kualitas Laba Pada Perusahaan Manufaktur Yang Terdaftar Di Bursa Efek Indonesia." Artikel IImiah: Sekolah Tinggi Ilmu Ekonomi Perbanas, 1-19.

Maulita, D., \& Putri, R. A. (2019). "Menguji Kualitas Laba Pada Perusahaan Makanan Dan Minuman." Universitas Serang Raya. 
Paulus, C. (2012). "Analisis faktor-faktor yang mempengaruhi kualitas laba." Jurnal Akuntansi, 1-59.

Setiawan, B. R. (2017). "Pengaruh Ukuran Perusahaan,Profitabilitas,Likuiditas Dan Leverage Terhadap Kualitas Laba." Menara IImu, Xi(77), 243-255.

Shintawati, V. R. (2011). "Pengaruh Board Diversity, Investment Opportunity Set (los), dan Kinerja Keuangan Terhadap Nilai Perusahaan Yang Terdaftar Di Bursa Efek Indonesia Tahun 2008." Universitas Sebelas Maret, 1-93.

Wati, Gahani Purnama \& Putra, I. Wayan. (2017). "Pengaruh Ukuran Perusahaan, Leverage, dan Good Corporare Governance Pada Kualitas Laba." E-Jurnal Akuntansi Universitas Udayana, 19, 137167.

Wulandari, Siti. (2018). "Pengaruh Pertumbuhan Laba, Size, Leverage, Investment Opportunity Set, Dan Good Corporate Governance Terhadap Kualitas Laba." Publikasih IImiah: Fakultas Ekonomi Dan Bisnis Universitas Muhammadiyah Surakarta.

Zein, Kartika Aulia. (2016). "Pengaruh Pertumbuhan Laba, Struktur Modal, Likuiditas Dan Komisaris Independen Terhadap Kualitas Laba Dengan Komisaris Independen Dimoderasi Oleh Kompetensi Komisaris Independen." Jurnal Online Mahasiswa Fakultas Ekonomi Universitas Riau, 3(1), 980-992.

Zulman, Mohamad \& Abbas D.S. (2017). "Pengaruh Ukuran Perusahaan, Struktur Modal, Likuiditas, Investment Opportunity Set (IOS), Dan Profitabilitas Terhadap Kualitas Laba." Universitas Muhammadiyah Internet : Tangerang

https://scholar.google.co.id/

https://www.idnfinancials.com/id/

https://www.idx.co.id/

http://britama.com/ 